\title{
Костянтин ШВАБІЙ
}

доктор економічних наук, професор, Університет ДФС України, Ірпінь, Україна, schwab2004@ukr.net

ORCID ID: 0000-0002-4837-391X

\section{ПРІОРИТЕТИ ПОДАТКОВОЇ ПОАІТИКИ ДЕРЖАВИ B УKРAїHI}

Вступ. Успішні державні рішення у бюджетній і податковій сфрерах здатні забезпечити соціально-економічний розвиток держави. В Україні за роки незалежності проведено чимало реформ у податковій сфрері, але відсутнє стійке соціально-економічне зростання. 3 огляду на це, актуальним є з'ясування напрямів трансформації податкової політики держави.

Мета - визначити напрямки трансформації податкової політики держави в Україні на середньострокову перспективу на основі аналізу існуючих структурних диспропорцій вітчизняної економіки та їі системи оподаткування.

Результати. Суть поданих тут пропозицій полягає у трансформації податкової політики держави, спрямованої на фрормування в Україні такої системи оподаткування, яка сприятиме довгостроковому, збалансованому, інклюзивному економічному зростанню $і$, водночас, забезпечуватиме достатній рівень доходів держави для виконання нею своїх функцій. Для цього, на нашу думку, в середньостроковій перспективі слід здійснити загальний перерозподіл податкового навантаження шляхом застосування усього переліку податків та їх складових елементів (платники, об‘єкти, база, пільги, ставки тощо), що має усунути диспропорції податкової системи України і сприятиме структурній модернізації вітчизняної економіки у довгостроковому періоді та зростанню рівня добровільності сплати податків. Зазначені пропозиції стосуються змін структури податкової системи та елементів податків і не стосуються відповідних змін в системі їх адміністрування, оскільки це - предмет окремої дискусії.

Висновки. Враховуючи існуючі структурні диспропорції податкової системи України, які призводять до регресивного розподілу податкового навантаження за рівнем доходів, один із першочергових заходів податкової політики держави полягає у зменшенні нормативної ставки ПДВ з 20\% до 15\%. Це дасть змогу підтримати купівельну спроможність вітчизняних домогосподарств. Основний позитивний ефект від цього полягає у створенні таких умов діяльності платників податків, за яких подальша діяльність на схемах фрормування фріктивного податкового кредиту стає економічно невигідною.

Ключові слова: податки, податкова система, структура податкової системи, структурні деформації, податкова політика держави.

Табл.: 2, рис.: 6, бібл.: 22.

(с) Костянтин Іванович Швабій, 2021 


\section{Константин ШВАБИЙ}

доктор экономических наук, профрессор, Университет ГНС Украины, Ирпень, Украина

\section{ПРИОРИТЕТЫ НАИОГОВОЙ ПОАИТИКИ ГОСУДАРСТВА В УКРАННЕ}

Введение. Успешные государственные решения в бюджетной и налоговой сферах способны обеспечить социально-экономическое развитие государства. В Украине за годы независимости проведено немало реформ в налоговой сфере, но отсутствует устойчивый социально-экономический рост. Учитывая это, актуальным является выяснение направлений трансформации налоговой политики государства.

Цель - определить направления трансформации налоговой политики государства в Украине на среднесрочную перспективу на основе анализа существующих структурных диспропорций отечественной экономики и ее системы налогообложения.

Результаты. Суть представленных предложений заключается в трансформации налоговой политики государства, направленной на фрормирование в Украине такой системы налогообложения, которая будет способствовать долгосрочному, сбалансированному, инклюзивному экономическому росту и одновременно обеспечивать достаточный уровень доходов государства для выполнения им своих функций. Для этого, по нашему мнению, в среднесрочной перспективе следует осуществить общее перераспределение налоговой нагрузки путем применения всего перечня налогов и их составляющих элементов (плательщики, объекты, база, льготы, ставки и т. п.), что должно привести к устранению диспропорций налоговой системы Украины, способствовать структурной модернизации отечественной экономики в долгосрочном периоде и росту уровня добровольной уплаты налогов. Указанные предложения касаются изменений структуры налоговой системы и элементов налогов и не касаются соответствующих изменений в системе их администрирования, поскольку это - предмет отдельной дискуссии.

Выводы. Учитывая существующие структурные диспропорции налоговой системы Украины, которые приводят к регрессивному распределению налоговой нагрузки по шкале доходов, одна из первоочередных мер налоговой политики государства заключается в уменьшении нормативной ставки НДС с 20\% до 15\%. Это позволит поддержать покупательную способность отечественных домохозяйств. Основной положительный эффрект от этого заключается в создании таких условий деятельности налогоплательщиков, при которых дальнейшая деятельность на схемах формирования фриктивного налогового кредита становится экономически невыгодной.

Ключевые слова: налоги, налоговая система, структура налоговой системы, структурные деформации, налоговая политика государства.

\section{Kostyantyn SHVABII}

Dr. Sc. (Economics), Prof., University of SFS of Ukraine, Irpin, Ukraine, schwab2004@ukr.net ORCID ID: 0000-0002-4837-391X

\section{THE PRIORITIES OF STATE TAX POLICY IN UKRAINE}

Introduction. Successful government decisions in the budget and tax areas able to provide socio-economic development of the country. Ukraine has undergone many tax reforms since independence, but there is no sustainable socio-economic growth. In view of this, it is important to clarify the directions of transformation of the state tax policy. 
The purpose of the article is to determine the directions of transformation of the tax policy of the state in Ukraine in the medium term based on the analysis of the existing structural disparities of the domestic economy and its taxation system.

Results. The research sets out the areas of state tax policy transformation for medium-term perspective. The proposals presented here are to transform the state tax policy aimed at forming a tax system in Ukraine that will promote long-term, balanced, inclusive economic growth and, at the same time, provide a sufficient level of state revenues to perform its functions. To do this, in our opinion, in the medium term there should be a general redistribution of the tax burden by applying the entire list of taxes and their constituent elements (taxpayers, objects of taxation, tax base, benefits, tax rates, etc.), which should lead to the elimination of disparities in the tax system of Ukraine, and will contribute to structural modernization of the domestic economy in the long run and increase the level of voluntary tax payments. These proposals mainly concern changes in the structure of the tax system and elements of taxes, and do not concern the corresponding changes in the system of their administration, as this is the subject of a separate discussion.

Conclusions. Given the existing structural disparities in the tax system of Ukraine, which lead to a regressive distribution of the tax burden by income level, one of the priority measures of state tax policy is to reduce the regulatory VAT rate from $20 \%$ to $15 \%$. This will support the purchasing power of domestic households. The main positive side effect of this is to create such conditions for taxpayers, under which further activities on the schemes of formation of fictitious tax credit becomes economically unprofitable.

Keywords: taxes, tax system, structure of tax system, structure deformation, state tax policy.

JEL Classification: $\mathrm{H} 20, \mathrm{H} 30$.

Постановка проблеми. У середньому податки забезпечують 80\% доходів державного та зведеного бюджетів України. Вони є невід'ємним і ключовим елементом системи публічних фрінансів, необхідною умовою життєдіяльності країни. Основне призначення податків - забезпечувати бюджет доходами, які держава витрачає на фінансування суспільних послуг, водночас всі, без винятку, податки в той чи іншій спосіб впливають на рішення економічних агентів. Як правило, ці рішення платників податків інші ніж ті, які вони приймали б в ідеальному світі, де податків не існує. Сукупність податків формує податкову систему країни, її структуру, яка також спотворює рішення економічних агентів, що призводить до втрати економічної ефективності.
Сучасна наукова думка не дає однозначної відповіді на питання, якою має бути оптимальна податкова структура. Теоретичні й емпіричні дослідження тривають. Проаналізувавши майже 30-річну історію функціонування вітчизняної системи оподаткування, порівнявши ії̈ з податковими системами і структурами різних країн світу, можемо наблизитися до відповіді на наступне питання. Яка структура податкової системи України $є$ оптимальною з огляду на вирішення двоєдиного завдання: 3 одного боку - досягнення стійких, збалансованих темпів економічного зростання, а з іншого досягнення такого рівня розподілу національного продукту, який забезпечить соціально-економічний поступ країни. Пошук оптимального поєднання цих взаємови- 
ключних вимог до податків визначає зміст податкової політики держави.

Аналіз останніх досліджень і публікацій. Сучасні підходи до формування податкової політики держави останніми роками дещо змінились. Якщо раніше вважалося, що податкова політика держави має формувати таку податкову систему країни, яка $є$ найменш шкідливою для економічного зростання, то сьогодні додатковим фактором $\epsilon$ відповідність політики інклюзивному економічному зростанню. Різні аспекти податкової політики висвітлені у роботах українських науковців 3. Варналія [1], А. Крисоватого, В. Мельника [2]. У праці К. Abdel-Kader i R. De Moоij викладені теоретичні і практичні аспекти формування податкової системи, що дає змогу підтримати інклюзивне економічне зростання [3]. Задля цього експерти ОЕСР розробили класифікацію податків за рівнем їх шкідливості на економіку [4]. J. Arnold, B. Brys, C. Heady, A. Johansson, L. Vartia [5] та K. McNabb [6] досліджували взаємозв'язок між структурою податкової системи й економічним зростанням за емпіричними даними різних країн і в різні періоди часу. Проте залишаються відкритими багато питань в цьому напрямку досліджень, які потребують вивчення. Зокрема, фрактори рівня розвитку економіки, ії̈ структури, наявність тіньового та офшорного секторів, інституційна спроможність контролюючих органів тощо $є$ тими чинниками, які можуть накладати на податкову політику і систему додаткові обмеження.

Метою дослідження $€$ визначення напрямів трансформації податкової політики держави в Україні на середньострокову перспективу на основі аналізу існуючих структурних диспропорцій вітчизняної економіки та її системи оподаткування.

Виклад основного матеріалу дослідження. Податкова система України характеризується істотними структурними дис- пропорціями, які зберігаються впродовж тривалого періоду і лише поглиблюються у часі. Вони виявляються в нерівномірному розподілі податкового навантаження в межах як податкової системи, так і за окремими її елементами.

Очевидно, що в сучасних умовах державна податкова політика і зміни структури податкової системи мають формуватися з урахуванням такого чинника, як міжнародна податкова конкуренція.

Класифікація агрегатних показників, які характеризують структуру податкової системи, здійснена за методологією ОЕСР [9]. Офріційні дані щодо країн ЄС і ОЕСР подано з джерел [10, 11], України - 3 [12, 13, 14]. Така класифікація не типова для України і використана лише для того, щоб в подальшому порівняльний аналіз структур податкових систем різних країн світу був коректним.

Якщо порівняти структуру основних податкових агрегатів України з країнами-сусідами, то можна побачити, що, незважаючи на те, що ми - одна з найбідніших країн Європи, частка прямих податків (DT) в Україні $\epsilon$ найбільшою (рис. 1). На рис. 1 позначено також непрямі податки, як IT, внески до ПФУ та інших фондів соціального страхування - SSC.

При цьому, якщо проаналізувати причини цієї структурної диспропорції в довгостроковій ретроспективі, то можна зрозуміти, що таке становище було сформовано за рахунок зростання розбіжності між часткою податку на доходи фрізичних осіб і податком на прибуток підприємств у ВВП (рис. 2). У 2019 р. частка прямих податків становила $12 \%$ ВВП.

Іншу структурну диспропорцію податкової системи України характеризує декомпозиція податкового агрегату непрямих податків (IT), що подана на рис. 3 .

Цей графрік наочно демонструє структурну деформацію не лише податкової системи, а 


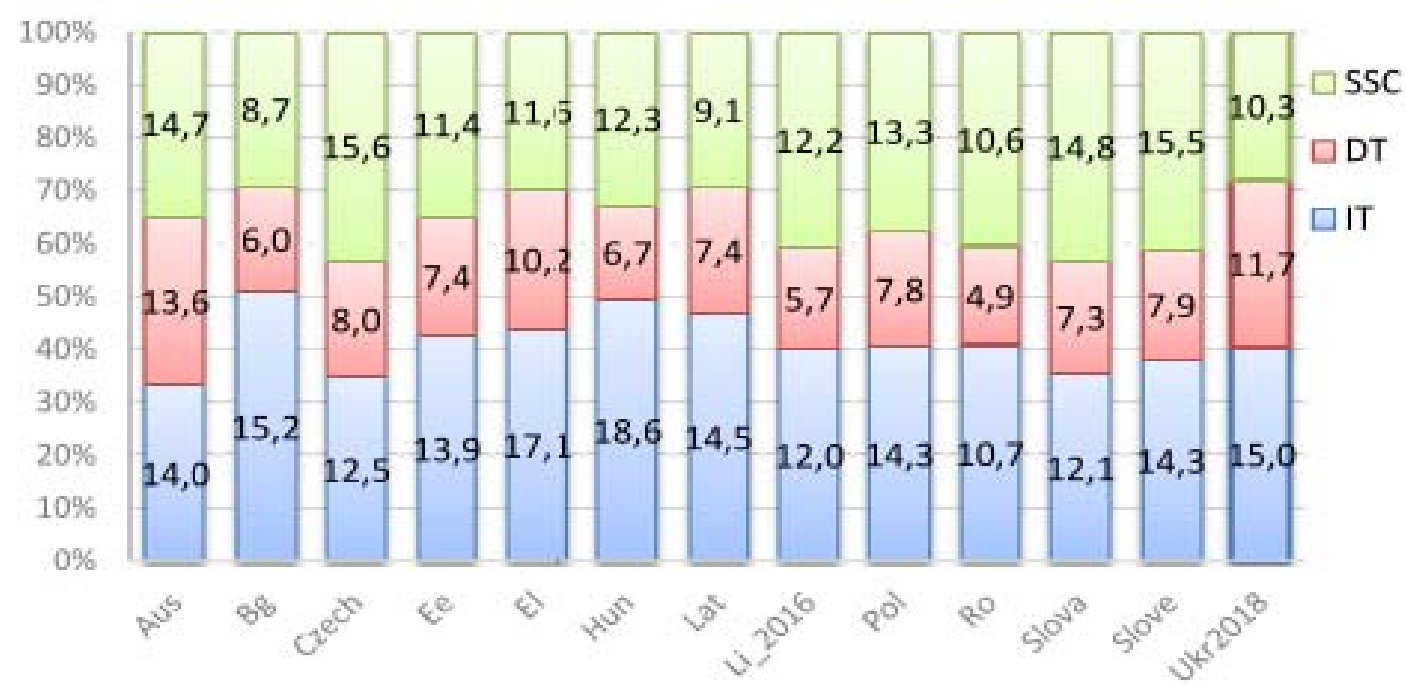

Рис. 1. Декомпозиція податкових агрегатів в Україні та країнах-сусідах, 2018 р.* * Побудовано на основі даних ДПСУ, згідно з класифікацією ОЕСР.

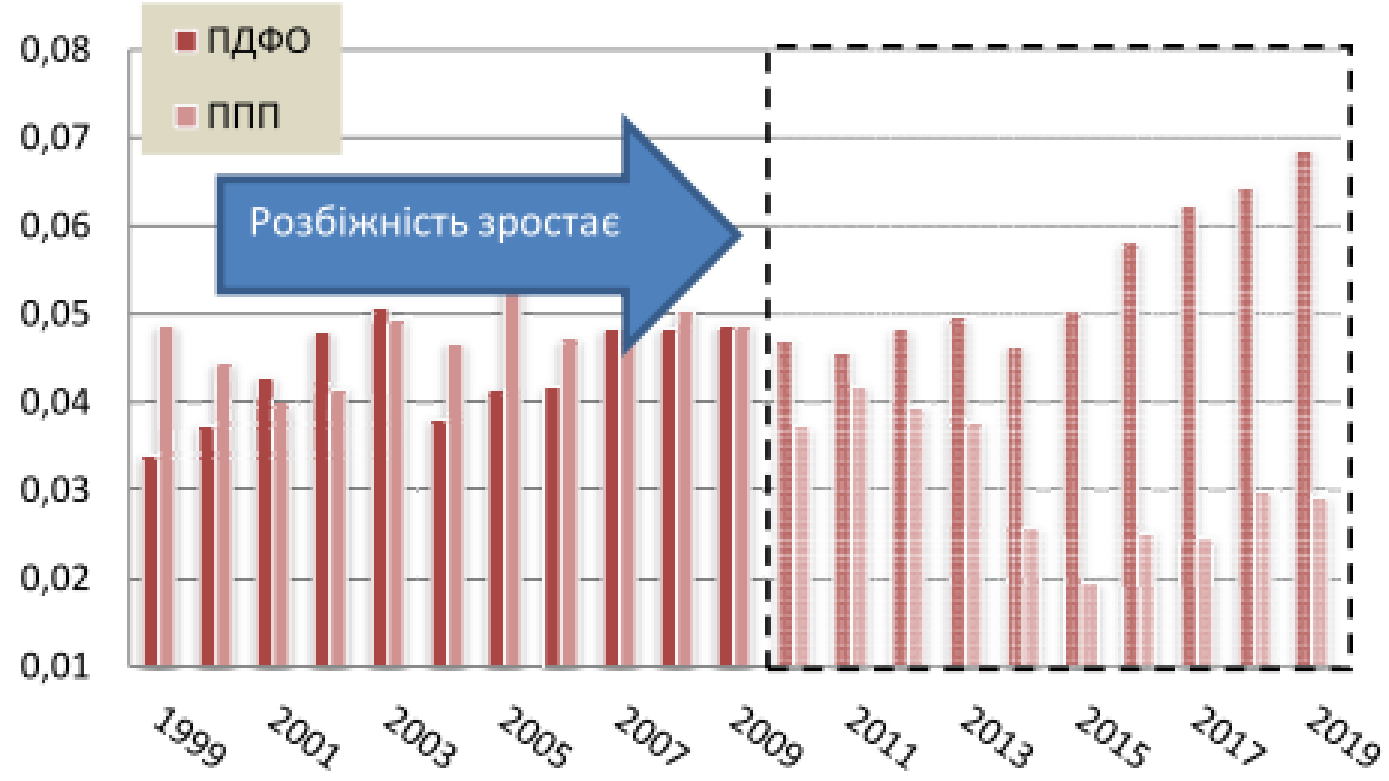

Рис. 2. Декомпозиція податкового агрегату DT за основними складовими, 1999-2019 pp.*

* Побудовано на основі даних ДПСУ, згідно з класифікацією ОЕСР. 


\section{ПОДАТКИ І ФІСКАЛЬНА ПОЛІТИКА}

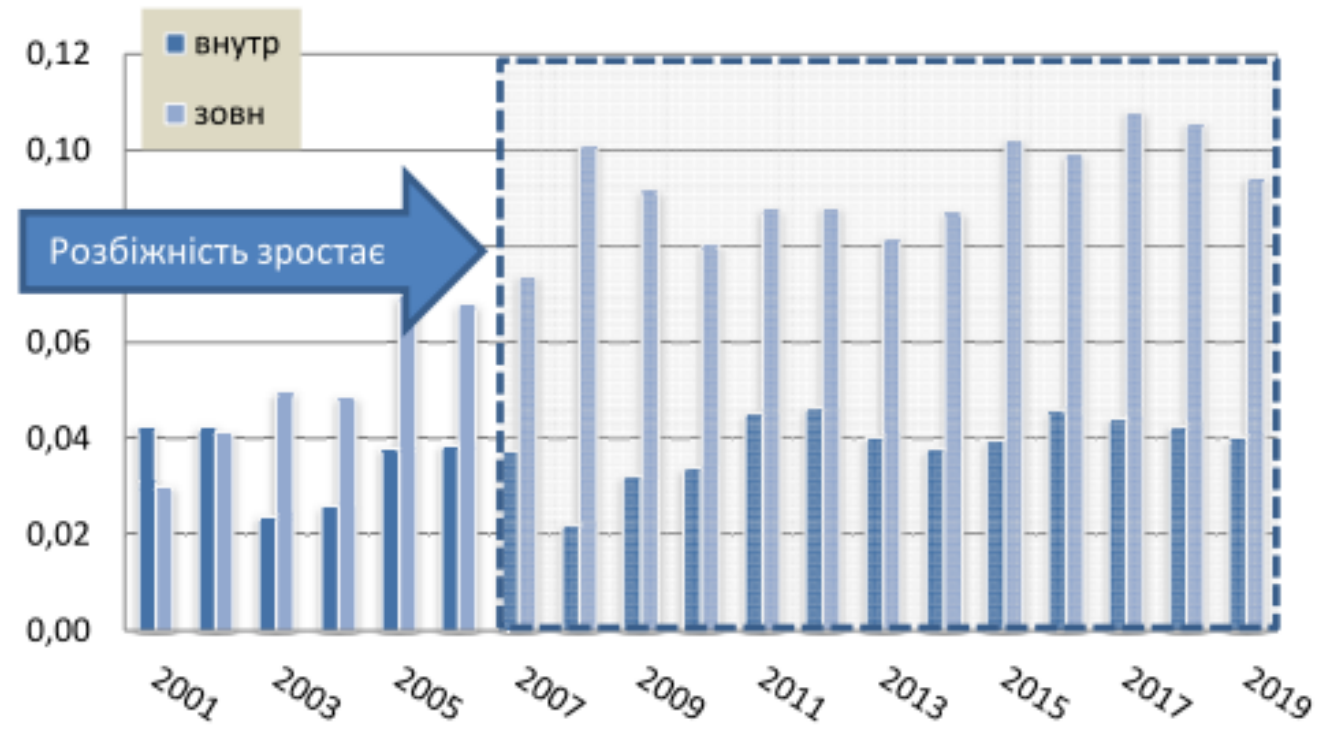

Рис. 3. Декомпозиція податкового агрегату IT за основними складовими, 2001-2019 рр.*

* Побудовано на основі даних ДПСУ, згідно з класифікацією ОЕСР.

й, що найкритичніше, економіки України. Існує стійка тенденція до збільшення податків на споживання з товарів імпортного виробництва над товарами, роботами і послугами внутрішнього. Отож, одним із ключових пріоритетів податкової політики держави $€$ досягнення ефректу імпортозаміщення шляхом податкового регулювання і досягнення стимулюючого ефректу для виробництв товарів, робіт, послуг з високою доданою вартістю в межах України.

У цьому контексті слід говорити не лише про структурні деформації податкової системи України, а також про деформації щодо стимулів до праці та інвестицій, що породжують податки. Одним із показників, який характеризує цей ефект, $€$ показник податкового клину (tax wedge), тобто податковий тягар, породжений персональним прибутковим податком, внесками до фондів соціального страхування.

Наочно його значення для України та для окремих країн-сусідів подано на рис. 4 . Для нашої держави у 2019 р. цей показник менший середнього значення по наведеній вибірці країн центрального та східноєвропейського регіону і лише трохи вищий, ніж у Болгарії, Греції, Польщі, Литві та Естонії. Незважаючи на це, вважаємо, що навіть в умовах жорстких бюджетних обмежень в Україні, головним чином пов'язаних 3 необхідністю покриття за рахунок коштів державного бюджету дефіциту Пенсійного фонду, існує резерв зменшення податкового навантаження на працю у середньостроковій перспективі шляхом перерозподілу податкового навантаження з податку на доходи фрізичних осіб за шкалою доходів.

У табл. 1 подано структуру податкової системи України за класифікацією ОЕСР, порівняно із усередненою структурою країн ОЕСР, країн Латинської Америки та 26 країн Африки. Ця вибірка охоплює 93 країни світу.

Слід зазначити, що головна особливість класифікації ОЕСР полягає у тому, що структура сукупного податкового наван- 


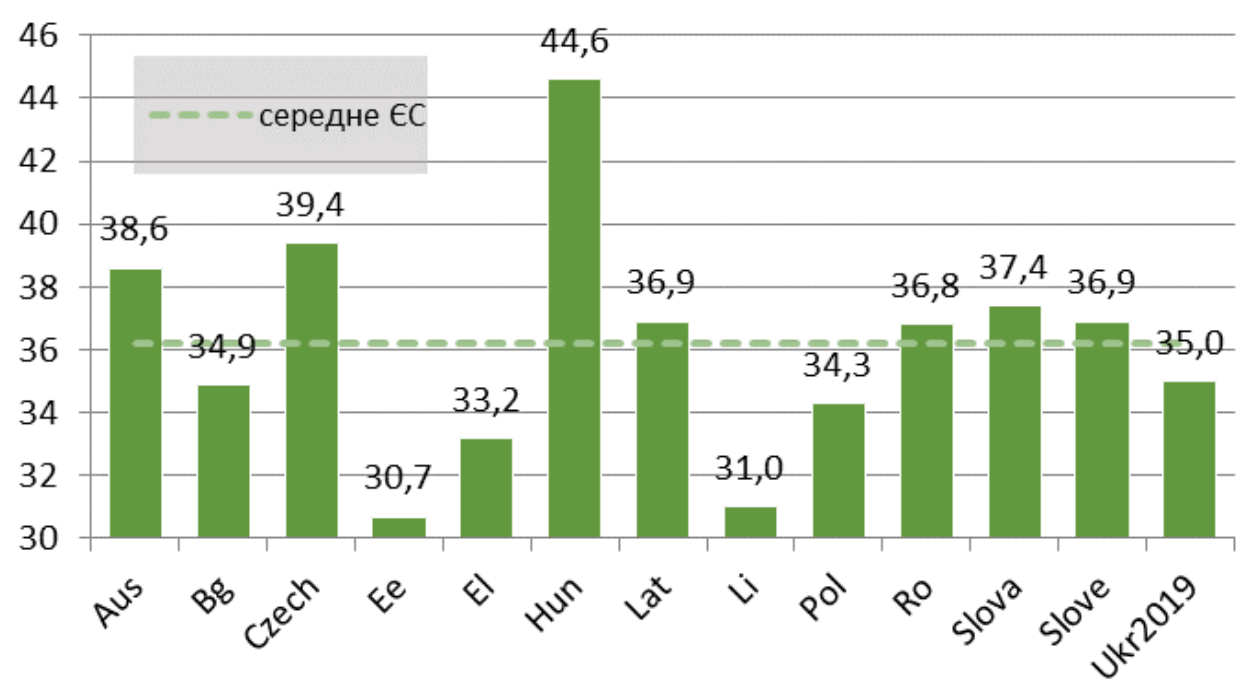

Рис. 4. Tax wedge в Україні та країнах-сусідах, 2019 р.*

* Побудовано на основі даних OECD.Stat.

Таблиця 1

Структура податкової системи України, порівняно 3 іншими країнами і регіонами світу, 2018 р.*

\begin{tabular}{|c|c|c|c|c|c|}
\hline Тип податків & $\begin{array}{c}\text { Код згідно класифікації } \\
\text { ОЕСР }\end{array}$ & Ukr_2018 & OECD_2018 & LAC_2018 & Africa(26) \\
\hline DT & 1000 & 0,31 & 0,34 & 0,28 & 0,39 \\
\hline SSC & $2000+3000$ & 0,27 & 0,27 & 0,17 & 0,07 \\
\hline Майно & 4000 & 0,02 & 0,06 & 0,04 & 0,02 \\
\hline IT & 5000 & 0,37 & 0,32 & 0,51 & 0,52 \\
\hline Інші & 6000 & 0,03 & 0,02 & 0,00 & 0,00 \\
\hline$\Sigma$ & & 1 & 1 & 1 & 1 \\
\hline
\end{tabular}

* Складено на основі даних OECD.Stat.

таження містить SSC, аналог вітчизняного ЄСВ. В Україні податковий коефіцієнт становить в середньому $37 \%$ ВВП, що навіть дещо вище аналогічного середнього показника для країн ОЕСР.

Наведені у табл. 1 дані свідчать, що за своєю структурою податкова система України не відповідає усередненим показникам жодного регіону світу. Проведені дослідження вказують на те, що для країн з низьким рівнем доходів, до яких, без сумніву, належить Україна, характерною $є$ така структура податкової системи, яка позначена її основними податковими агрегатами (прямі податки (DT), непрямі (IT) та внески до фондів соціального страхування (SSC), коли для бідних країн доміную- 
чими є непрямі податки, для багатих - прямі [15]. У середньому для вибірки таких країн, де частка ПДВ у структурі податкових надходжень бюджету вища за 30\%, частка прямих податків перебуває на рівні 16\% для персонального прибуткового податку і 15\% - для корпоративного. В структурі податкових надходжень зведеного бюджету України ПДФО становить більше $20 \%$, податок на прибуток 8\% і ПДВ - 35\%. На рис. 5 подана динаміка зміни структури ПСУ впродовж 20 років за показниками, згідно з класиффікацією ОЕСР.

Найбільш помітні зміни полягають у зміні наступних складових податкової системи. За цей період збільшилась частка податку на доходи фрізичних осіб з 15\% до $20 \%$, зменшилась частка податку на прибуток з 18\% до 12\%, збільшилась частка ПдВ з 21\% до $25 \%$ і акцизного податку - з 5\% до 9\% в структурі податкових надходжень Зведеного бюджету України.
Дані рис. 6 свідчать, що, порівняно з країнами-сусідами, в Україні найбільшу частку в надходженнях бюджету становить ПДВ. Водночас SSC - одна із найнижчих часток.

У контексті оцінки структури податкової системи України, виявлення наявних її диспропорцій, важливе питання полягає у тому, яка саме структура податкової системи найбільш сприятлива для економічного зростання.

Як зазначалося раніше, в роботі [5] подана така класифікація, де емпіричним шляхом виявлено, що, наприклад, податки на майно чи на споживання $€$ менш шкідливими, порівняно з прямими податками та SSC. Водночас, у дослідженні K. McNabb зазначається, що такі висновки, отримані за результатами аналізу даних багатих країн, не завжди релевантні для країн з низькими доходами, в яких важливе значення мають інші фрактори впливу, а також очевидно, що

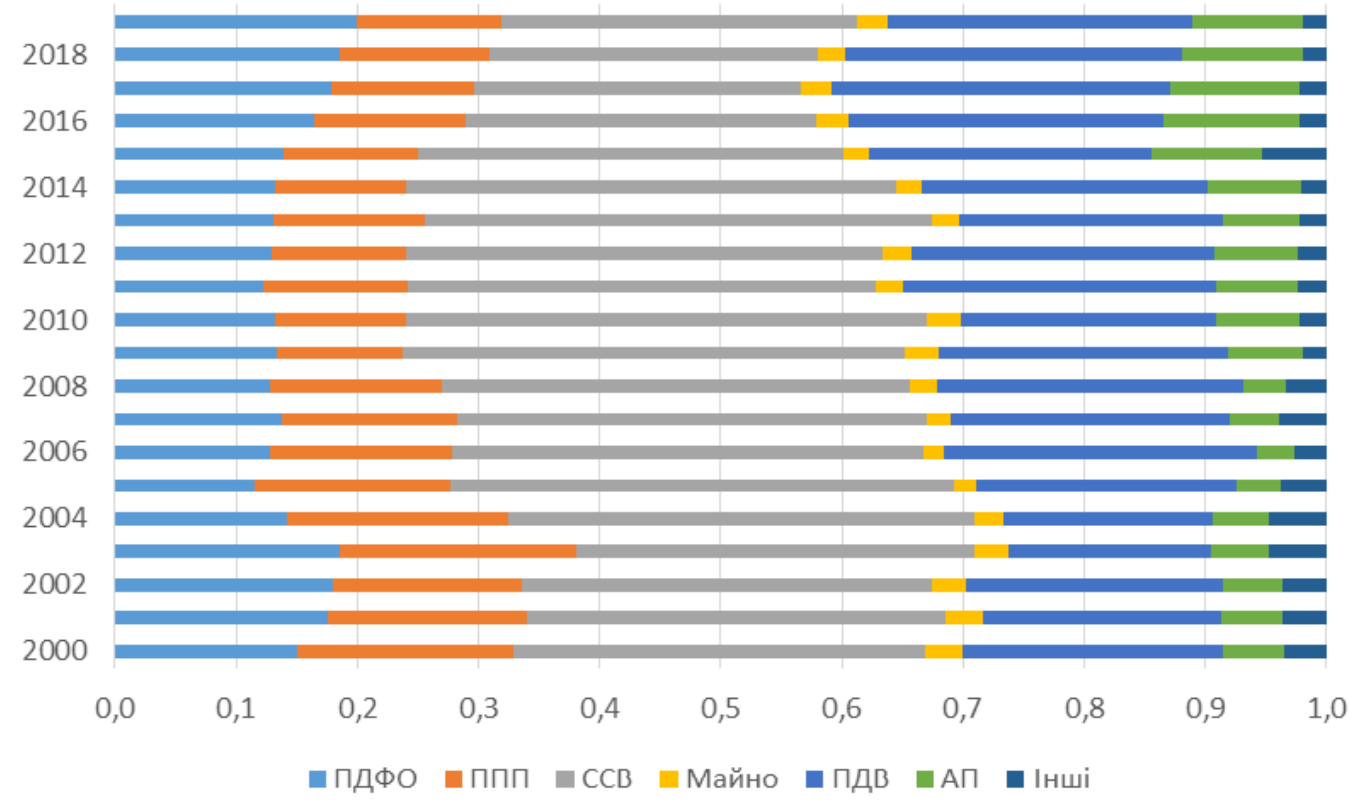

Рис. 5. Структура податкової системи України (\% загальних податкових надходжень Зведеного бюджету України), 2000-2019 рр.*

* Побудовано на основі даних ДПСУ, ДКСу. 


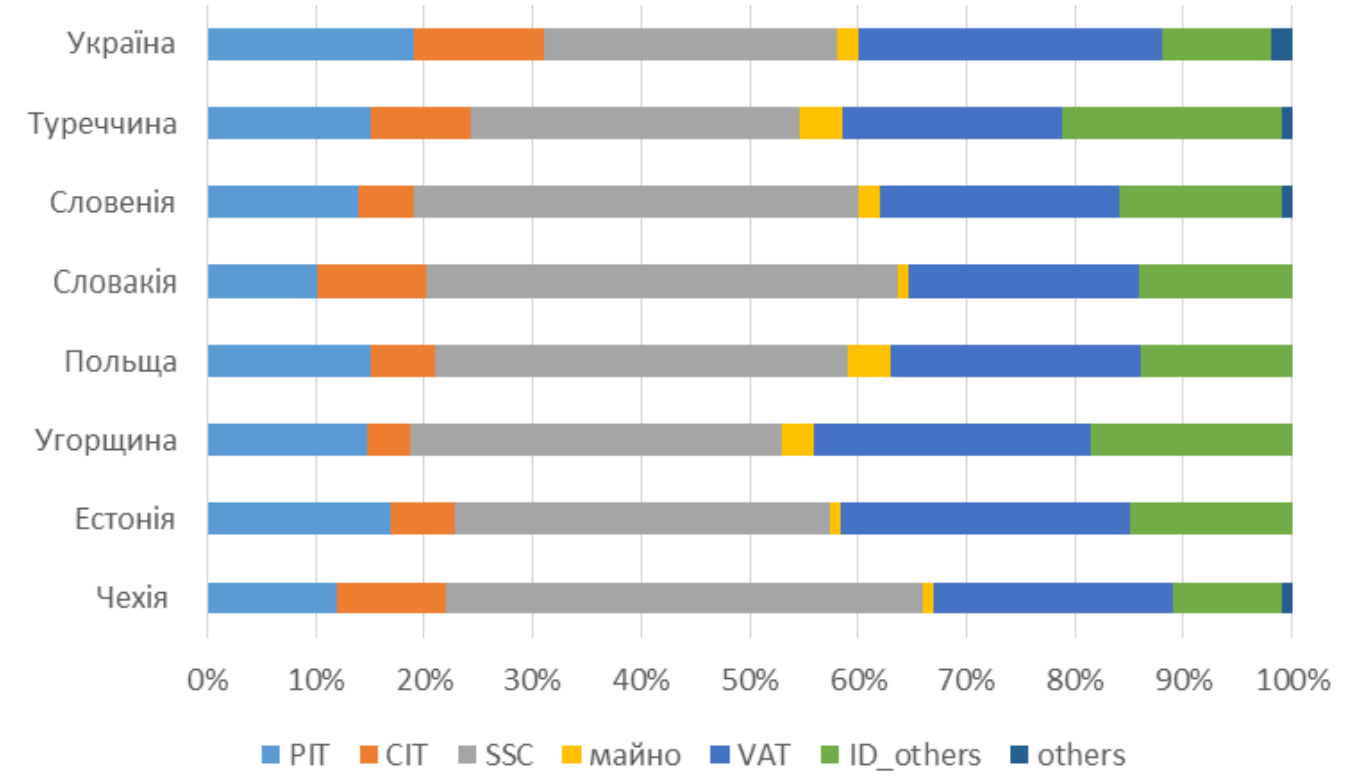

Рис. 6. Структура податкової системи України та окремих країн-сусідів (\% загальних податкових надходжень Зведеного бюджету України), станом на 2018 р.* * Побудовано на основі даних ДПСУ, OECD.Stat.

в кожному індивідуальному випадку значення має стадія економічного розвитку, на якій перебуває країна [6].

Одна з найбільших часток ПДВ в структурі доходів бюджету серед усіх держав світу - в Чилі. Згідно з даними ОЕСР, станом на 2018 р. частка ПДВ становила 40\% сукупних податкових надходжень зведеного бюджету, акцизного податку - 6,9\%, податків на майно - 5,1\%, SSC - 6,9\%, CIT - 22,1\%, а PIT - 6,7\%. Як бачимо, порівняно з Україною, втричі менше податкове навантаження на доходи населення, у чотири рази менше SSC і майже удвічі більше CIT. Очевидно, що ця країна обрала за основу зовсім іншу модель формування структури податкової системи.

Якщо орієнтуватися на структуру податкових систем саме країн ОЕСР, а не Латинської Америки чи Африки, то стає зрозуміло, які саме зміни потрібні в структурі податкової системи України (табл. 2).
Дані табл. 2 вказують на те, які саме об'єкти оподаткування мають певні резерви для збільшення або зменшення своєї частки в структурі податкової системи України. Зокрема, майно (нерухомість) має істотний потенціал збільшення, а оподаткування споживання, навпаки, має бути зменшеним майже на третину в загальній структурі. Зменшення потребує оподаткування прибутків підприємств, а підвищення - оподаткування доходів фізичних осіб.

У контексті останнього зауваження слід звернути увагу на те, що, на нашу думку, збільшення податкового навантаження на доходи фізичних осіб має відбуватися, насамперед, шляхом перерозподілу податкового тягаря на більш заможні верстви населення як через запровадження певної шкали прогресивних ставок податку на доходи фрізичних осіб, так й через запровадження податку на багатство. Іншими словами, необхідно зробити його більш про- 
Деталізована структура ПСУ, порівняно $з$ країнами ОЕСР, 2018 р. *

\begin{tabular}{|c|c|c|c|}
\hline Тип податку & Ukr_2018 & OECD_2018 & Aukr_OECD2018 \\
\hline PIT & 0,19 & 0,24 & $+0,05$ \\
\hline CIT & 0,12 & 0,10 & $-0,02$ \\
\hline SSC+Payroll Taxes & 0,27 & 0,27 & 0 \\
\hline Податки на майно & 0,02 & 0,06 & $+0,04$ \\
\hline ПДВ & 0,27 & 0,20 & $-0,07$ \\
\hline Інші непрямі податки & 0,10 & 0,12 & $+0,02$ \\
\hline Інші & 0,03 & 0,01 & $-0,02$ \\
\hline $\boldsymbol{\Sigma}$ & 1 & 1 & 0 \\
\hline
\end{tabular}

* Складено на основі даних OECD.Stat.

гресивним, подібно до того, як здійснюється розподіл податкового навантаження за рівнями доходів, наприклад, у США. Зокрема, більше 90\% податкового тягаря з РІТ сплачують менше 20\% громадян з доходами 100 тис. дол./рік і більше. В Україні майже $85 \%$ доходів від сплати ПДФО надходить до зведеного бюджету від доходів у вигляді заробітної плати, яку отримують 90\% працюючих громадян (з середньою заробітною платою станом на жовтень 2020 р. трохи більше 12 тис. грн/міс.). Решта об'єктів оподаткування (майно, підприємницькі та інвестиційні доходи) забезпечують приблизно 10\% податкових надходжень з податку на доходи фрізичних осіб.

Ми розуміємо, що порівнювати таку структурну статистику США і України не зовсім коректно, але наводимо її для розуміння глибини наявних структурних диспропорцій. Авторські дослідження вказують на те, що розподіл податкового навантаження з податку на доходи фрізичних осіб в Україні $€$ регресивним [10]. Його посилює надмірне податкове навантаження, яке фрормується за рахунок застосування регресивного ПДВ. Така структурна деформація податкової системи України є, однозначно, небажаною іiї характеристикою, що в ході реалізації реформаційних заходів у сфері податкової політики держави найчастіше не береться до уваги. Наслідок такого стану справ полягає у вкрай високій опортуністичності основної маси платників податків. А це означає, що досягти прийнятного рівня добровільності сплати податків неможливо, доки розподіл податкового навантаження не стане більш рівномірним або навіть прогресивним.

Слід зазначити наступне. До початку епідемії COVID-19 нормативні ставки податку залишались незмінними, лише Китай зменшив ставку ПДВ з 17 до 13\%. 32015 р. до 2019 р. у світі спостерігалась тенденція до помірного збільшення ставки ПДВ, що було зумовлено необхідністю подальшої фріскальної консолідації бюджетів країн світу [16]. 3 моменту спалаху епідемії, внаслідок введення локдауну і падіння рівня доходів громадян, Китай, Кіпр і Норвегія оголосили про тимчасове зменшення нормативних і зменшених ставок ПДВ з метою підтримки споживання домогосподарств. 3 тих же мотивів згодом Австрія, Німеччина та Великобританія оголосили про тимчасове зменшення ставок ПДВ до кінця 2020 р. або до початку 2021 р. При цьому, 
якщо Австрія та Великобританія зменшили нормативні ставки ПДВ в цільовий спосіб, з метою підтримки споживання медичних і культурних послуг, то Німеччина зменшила ставку ПДВ для всіх товарів і послуг відразу [17]. При цьому, слід звернути увагу, що показники ВВП на особу в цих країнах, а відповідно й доходи населення, є значно вищими за українські. Згідно з даними ОЕСР, крім зазначених вище країн, з метою підтримки споживання нормативні ставки ПДВ зменшили ще такі країни, як Ямайка, Казахстан, Кенія, Туреччина. Збільшила лише Саудівська Аравія [18].

Як засвідчують цифри у табл. 2, збільшення потребує оподаткування підакцизних товарів. Окрім позитивного фріскального ефекту для Державного бюджету України, підвищення ставок акцизного податку та ефективності його адміністрування дає змогу зменшити нерівномірність розподілу податкового навантаження за різними категоріями доходу, оскільки підакцизна продукція має більшу питому вагу в споживанні заможних верств населення.

Основним резервом збільшення податкових надходжень від сплати акцизного податку є такі об'єкти оподаткування, як електронні сигарети і солодкі безалкогольні напої. Йдеться про напої із високим вмістом цукру: солодкі газовані напої; енергетичні напої; спортивні напої; холодний чай; солодкі кавові напої; будь-які інші напої, до яких додані цукроза чи фруктоза.

Поширення акцизного податку на такий об'єкт оподаткування є однією з рекомендацій Всесвітньої організації охорони здоров'я, які спрямовані на запобігання нездоровому харчуванню та компенсацію зростаючих економічних витрат, пов'язаних із ризиками для здоров'я, зокрема - ожиріння, карієсу, розвитку серцево-судинних захворювань, діабету другого типу, раку кишечника тощо. Зважаючи на необхідність обмеження споживання вільного цукру серед населення України, впровадження акцизного податку на солодкі безалкогольні напої $€$ доволі актуальним. Так, протягом останніх десяти років кількість пацієнтів 3 діабетом другого типу збільшилась майже на $50 \%$.

Акцизний податок на такі напої активно впроваджується в різних країнах світу, зокрема в деяких штатах США та країнах Європи - Бельгії, Великобританії, Іспанії (Каталонії), Ірландії, Норвегії, Латвії, Португалії, Угорщині, Хорватії, Фінляндії та Франції. В країнах Європи середня гранична ставка становить 0,1679 євро за літр. У Бельгії, Великобританії, Ірландії, Іспанії (Каталонії), Норвегії, Португалії, Фінляндії застосовують диференційований підхід до встановлення ставок, залежно від вмісту цукру в безалкогольному напої. За оцінками експертів, у Польщі запровадження АП "на цукор" дасть змогу залучити до бюджету країни 3 млрд злотих (670 млн євро) у 2021 р. [19].

Якщо встановити ставку акцизного податку на солодкі безалкогольні напої в Україні на рівні 2 грн/л, можна забезпечити податкові надходження до бюджету в сумі 3 млрд грн на рік.

Значний фіскальний резерв полягає в збільшенні оподаткування майна. Резерви підвищення фоскальної ефективності податку на нерухоме майно, відмінне від земельної ділянки, існують як в удосконаленні процедур його адміністрування, так і в підвищенні ставок податку. У 2019 р. від сплати фрізичними особами податку на нерухоме майно надійшло 4,9 млрд грн. При цьому, за оцінками експертів Міністерства фінансів, через відсутність повної бази об'єктів оподаткування в Держреєстрі речових прав на нерухоме майно, несплата податку на нерухоме житлове та нежитлове 
майно завдає збитків місцевим бюджетам в сумі майже 2 млрд грн щорічно [20].

При цьому фахівці зазначають, що у разі створення повноцінного реєстру нерухомого майна з прив'язкою до земельних ділянок і запровадження базою оподаткування не площі об'єкта нерухомості, а його ринкової вартості, обсяги надходжень від сплати податку на нерухомість можуть зрости в 4,8 рази - до 120 млрд грн на рік [21].

В контексті удосконалення інституційних засад адміністрування екологічного податку найбільші переваги має запровадження непрямого податку на споживання енергоресурсів, залежно від емісійних коефіцієнтів викидів двоокису вуглецю. Це дасть змогу встановити ціну, яку платники податків мають сплачувати за кожну тонну викидів $\mathrm{CO}_{2}$ задіяти статичну та динамічну ефективність цього виду екологічних податків, що полягає у здатності забезпечувати зменшення емісії $\mathrm{CO}_{2}$ найменш витратним способом та впливати на процес технологічних змін через створення стимулів до розробки та впровадження інноваційних технологій для зменшення викидів. Також це сприятиме спрощенню адміністрування такого податку та стимулюватиме економічних агентів до зміни споживчої та виробничої поведінки, що в кінцевому підсумку сприятиме зменшенню енергоємності та карбоноємності ВВП і протидіятиме зміні клімату.

Висновки. Таким чином, зазначені заходи $є$ ключовими пріоритетами у сфері податкової політики держави на середньострокову перспективу. У подальшому, враховуючи існуючі бюджетні обмеження державного і місцевих бюджетів, з метою виправлення структурних диспропорцій податкової системи України, слід розглядати можливості запровадження помірно прогресивної шкали ставок податку на доходи фрізичних осіб з одночасним поступовим на- ближенням неоподатковуваного доходу до законодавчо визначеного прожиткового мінімуму безвідносно до рівня доходів, отриманих у вигляді заробітної плати, обмеження щодо яких встановлено пп. 4.1. ст. 169 Податкового кодексу України. Це дасть змогу підвищити прогресивність перерозподілу податкового навантаження за рівнями доходів. Таку трансформацію податкової системи України слід здійснювати протягом середньострокового періоду (3-5 років), під час якого також розпочати градаційну зміну пропорцій сплати ЄСВ між роботодавцем і найманим працівником шляхом зменшення частки для роботодавців і відповідного збільшення частки ЄСВ, яку сплачують наймані працівники. При цьому частка коштів ЄСВ має бути спрямована до накопичувальної недержавної пенсійної системи, а саме - недержавних пенсійних фондів, але ці зміни потрібно також запроваджувати в комплексі з реформою системи пенсійного забезпечення в Україні.

\section{Список використаних джерел}

1. Варналій 3. С. Податкова система України: проблеми функціонування та шляхи реформування. Економіка і регіон. 2017. № 5. С. 5-9.

2. Крисоватий А. І., Мельник В. М., Кощук Т. В. Сутність та концептуальні онови формування податкової політики в умовах євроінтеграційних процесів: Економіка України. 2016. № 1. C. 35-51.

3. Tax policy and inclusive growth. URL : https://www.imf.org/en/Publications/WP/lssues/2020/12/04/Tax-Policy-and-InclusiveGrowth-49902.

4. Tax design for inclusive economic growth. URL : https://www.oecd.org/tax/tax-policy/tax-designfor-inclusive-economic-growth-web-brochure.pdf.

5. Arnold, J. M., Brys, B., Heady, C., Johansson, A., \& Vartia, L. Tax Policy for Economic Recovery and Growth. OECD Economics Department 


\section{ПОДАТКИ І ФІСКАЛЬНА ПОЛІТИКА}

Working Papers. 2008. URL : https://econpapers. repec.org/paper/ukcukcedp/0925.htm/

6. McNabb K. Tax structures and economic growth. WIDER Working Paper 2016. № 148. URL : https://www.wider.unu.edu/publication/taxstructures-and-economic-growth.

7. Tax policy : EU survey. URL : https:// ec.europa.eu/taxation customs/business/company-tax/tax-good-governance/european-semester/ tax-policies-european-union-survey en.

8. Xing J. Does tax structure affect economic growth? Empirical evidence from OECD countries. 2012. URL : https://www.researchgate.net/publication/241753520 Does tax structure affect economic growth Empirical evidence from OECD countries.

9. Revenue Statistics 1965-2017. INTERPRETATIVE GUIDE. URL : https://www.oecd.org/tax/ tax-policy/oecd-classification-taxes-interpretativeguide.pdf.

10. Eurostat. Your key to European Statistics. URL : https://ec.europa.eu/eurostat/data/database.

11. Online services and databases for taxation. URL : https://ec.europa.eu/taxation customs/ online-services-and-databases-taxation en.

12. Звітність. Державна казначейська служба України. URL : https://www.treasury. gov.ua/ua/file-storage/vikonannya-derzhavnogobyudzhetu;:

13. Звіт про виконання бюджету Пенсійного фронду України. URL : https://www.pfu.gov. ua/byudzhet/zvit-pro-vykonannya-byudzhetupensijnogo-fondu-ukrayiny/.

14. Державний веб-портал бюджету для громадян. URL : https://openbudget.gov.ua/.

15. Modica E., Laudage S., Harding M. Domestic revenue mobilization. A new database on tax levels and structures in 80 countries. OECD Taxation Working Papers. URL : https://www.oecdilibrary.org/docserver/a87feae8-en.pdf?expires $=15$ 86320838\&id=id\&accname $=$ quest\&checksum $=787$ F827B48D7F974F022294FCB618703.
16. Tax policy reforms 2020. OECD and selected partner economies. URL : https://www.oecd. org/tax/tax-policy-reforms-26173433.htm.

17. Tax and fiscal policy response to the coronavirus crisis : strengthening confidence and resilience. URL : https://www.oecd.org/ctp/tax-policy/tax-andfiscal-policy-in-response-to-the-coronavirus-crisisstrengthening-confidence-and-resilience.htm.

18. Tax policy responses to COVID-19. Data. URL : https://www.oecd.org/tax/.

19. Податок на иукор у Польщі. Якими фріскальними методами вирішувати важливі завдання. URL : https://uastrategy.eu/projects/vpolshch-vprovadzhuyut-podatok-na-cukor.

20. Неповна сплата податку на нерухоме майно. У Мінфріні порахували втрати місцевих бюджетів. URL : https://www.epravda.com.ual news/2020/05/22/660854/.

21. Сімонова Л., Букрєєва О. Квартира без землі - що голова без тулуба. Електронний реcypc. URL : https://zn.ua/ukr/finances/kvartira-bezzemli-shcho-holova-bez-tuluba.html.

22. Статистика. Макроекономічні показники. НБУ. URL : https://bank.gov.ua/statistic/ macro-indicators\#4.

\section{References}

1. Varnalii, Z. S. (2017). Podatkova systema Ukrainy: problemy funktsionuvannia ta shliakhy reformuvannia [The tax system of Ukraine: problems of functioning and ways of reforming]. Ekonomika $i$ rehion - Economy and region, 5, 5-9 [in Ukrainian].

2. Krysovatyi, A. I., Melnyk, V. M., Koshchuk, T. V. (2016). Sutnist ta kontseptualni onovy formuvannia podatkovoi polityky $v$ umovakh yevrointehratsiinykh protsesiv [The essence and conceptual updates of tax policy formation in the conditions of European integration processes]. Ekonomika Ukrainy - Economy of Ukraine, 1, 35-51 [in Ukrainian].

3. Tax policy and inclusive growth. Available at: https://www.imf.org/en/Publications/ WP/Issues/2020/12/04/Tax-Policy-and-InclusiveGrowth-49902. 
4. Tax design for inclusive economic growth. Available at: https://www.oecd.org/tax/tax-policy/ tax-design-for-inclusive-economic-growth-webbrochure.pdf.

5. Arnold, J. M., Brys, B., Heady, C., Johansson, A., \& Vartia, L. (2008). Tax policy for economic recovery and growth. OECD Economics Department Working Papers. Available at: https://econpapers.repec.org/paper/ukcukcedp/0925.htm.

6. McNabb, K. (2016). Tax structures and economic growth. WIDER Working Paper, 148. Available at: https://www.wider.unu.edu/publication/tax-structures-and-economic-growth.

7. Tax policy: EU survey. Available at: https:// ec.europa.eu/taxation customs/business/company-tax/tax-good-governance/european-semester/ tax-policies-european-union-survey en.

8. Xing, J. (2012). Does tax structure affect economic growth? Empirical evidence from OECD countries. Available at: https://www.researchgate. net/publication/241753520 Does tax structure affect economic growth Empirical evidence from_OECD_countries.

9. Revenue Statistics 1965-2017. INTERPRETATIVE GUIDE. Available at: https://www.oecd.org/ tax/tax-policy/oecd-classification-taxes-interpretative-guide.pdf.

10. Eurostat. Your key to European Statistics. Available at: https://ec.europa.eu/eurostat/data/database.

11. Online services and databases for taxation. Available at: https://ec.europa.eu/taxation_customs/online-services-and-databases-taxation_en.

12. Zvitnist [Reporting]. Derzhavna kaznacheiska sluzhba Ukrainy - State Treasury Service of Ukraine. Available at: https://www.treasury. gov.ua/ua/file-storage/vikonannya-derzhavnogobyudzhetu;:

13. Zvit pro vykonannia biudzhetu Pensiinoho fondu Ukrainy [Report on the implementation of the budget of the Pension Fund of Ukraine]. Available at: https://www.pfu.gov.ua/byudzhet/zvit-pro-vykonannya-byudzhetu-pensijnogo-fondu-ukrayiny/.
14. Derzhavnyi veb-portal biudzhetu dlia hromadian [State web portal of the budget for citizens]. Available at: https:/lopenbudget.gov.ual.

15. Modica, E., Laudage, S., Harding, M. Domestic revenue mobilization : A new database on tax levels and structures in 80 countries. OECD Taxation Working Papers. Available at: https://www. oecd-ilibrary.org/docserver/a87feae8-en.pdf?expir es=1586320838\&id=id\&accname=guest\&checksu $\underline{m=787 F 827 B 48 D 7 F 974 F 022294 F C B 618703 .}$

16. Tax policy reforms 2020. OECD and selected partner economies. Available at: https://www. oecd.org/tax/tax-policy-reforms-26173433.htm.

17. Tax and fiscal policy response to the coronavirus crisis: strengthening confidence and resilience. Available at: https://www.oecd.org/ctp/ tax-policy/tax-and-fiscal-policy-in-response-to-thecoronavirus-crisis-strengthening-confidence-andresilience.htm.

18. Tax policy responses to COVID-19. Data. Available at: https://www.oecd.org/tax/.

19. Podatok na tsukor u Polshchi. Yakymy fiskalnymy metodamy vyrishuvaty vazhlyvi zavdannia [Sugar tax in Poland. What fiscal methods to solve important tasks]. Available at: https://uastrategy.eul projects/v-polshch-vprovadzhuyut-podatok-na-cukor.

20. Nepovna splata podatku na nerukhome maino. $U$ Minfini porakhuvaly vtraty mistsevykh biudzhetiv [Incomplete payment of real estate tax. The Ministry of Finance calculated the losses of local budgets]. Available at: https://www.epravda. com.ua/news/2020/05/22/660854/.

21. Simonova, L., Bukrieieva, O. Kvartyra bez zemli - shcho holova bez tuluba [An apartment without land is like a head without body]. Available at: $\quad$ https://zn.ua/ukr/finances/kvartira-bez-zemlishcho-holova-bez-tuluba.html.

22. Statystyka. Makroekonomichni pokaznyky [Statistics. Macroeconomic indicators] NBU. Available at: https://bank.gov.ua/statistic/macro-indicators\#4.

Стаття надійшла до редакції 19.10.2020. 